\title{
PRINSIP KEBEBASAN BERKONTRAK DALAM PENYUSUNAN KONTRAK
}

\author{
Oleh
}

\author{
Ghansam Anand
}

\begin{abstract}
Abstrak
Hampir dapat dipastikan bahwa dalam dunia hukum bisnis di abad mendatang akan merupakan abad kontrak. Untuk menunjang kegiatan-kegiatan bisnis atau transaksitransaksi dagang yang semakin modern dan mengglobal tersebut, peranan hukum kontrak sangat diperlukan. Kontrak yang dibuat pun semakin berkembang, klausul-kalusul yang dimuat dalam kontrak tersebut disesuaikan dengan kebutuhan-kebutuhan transaksi. Terdapat keterkaitan yang erat antara perluasan pasar dengan kebebasan berkontrak, pihak yang lebih memiliki kekuatan pasar mempunyai bargaining position yang lebih tinggi untuk memaksakan kehendaknya kepada pihak yang lemah.
\end{abstract}

Kata Kunci: Kontrak, Kebebasan Berkontrak, Para pihak dalam Kontrak

\section{Pendahuluan}

Hukum perjanjian di Indonesia menganut beberapa asas, antara lain: asas kebebasan mengadakan perjanjian (partij otonomi), asas konsensualisme (persesuaian kehendak), asas kebiasaan, asas kekuatan mengikat, asas persamaan hukum, asas keseimbangan, asas kepentingan umum, asas moral, asas kepatuhan, asas perlindungan bagi golongan yang lemah, dan asas sistem terbuka. Dalam hukum perjanjian dianut apa yang disebut dalam ilmu hukum yaitu "asas kebebasan berkontrak" asas ini berarti bahwa kebebasan seseorang untuk membuat perjanjian macam apapun dan berisi apa saja sesuai dengan kepentingannya dalam batasbatas kesusilaan dan ketertiban umum, sekalipun perjanjian itu bertentangan dengan pasal-pasal hukum perjanjian. Asas kebebasan berkontrak lahir pada abad 17 $\mathrm{M}$, asas ini memiliki daya kerja yang sangat kuat, yang berarti kebebasannya tidak boleh dibatasi, baik rasa keadilan masyarakat maupun oleh aturan perundang-undangan. Asas ini muncul bersamaan dengan lahirnya paham ekonomi klasik yang mengagungkan Laissez Faire (persaingan bebas), yang dipelopori oleh Adam Smith. Sumber dari kebebasan berkontrak adalah kebebasan individu sehingga yang merupakan titik tolaknya adalah kepentingan individu pula. Dengan demikian dapat dipahami

\footnotetext{
*Pengamat Hukum, gansam_anand@yahoo.com
} 
bahwa kebebasan individu memberikan kepadanya kebebasan untuk berkontrak. Berlakunya asas konsensualisme menurut hukum perjianjian Indonesia memantapkan adanya asas kebebasan berkontrak. Tanpa sepakat dari salah satu pihak yang membuat perjanjian, Tanpa sepakat maka perjanjian yang dibuat dapat dibatalkan.

Disamping itu asas ini juga dipahami: Pertama, bahwa hukum tidak dapat membatasi syarat-syarat yang boleh diperjanjikan oleh para pihak. Ini berarti bahwa hukum tidak boleh membatasi apa yang telah diperjanjikan oleh para pihak yang telah mengadakan perjanjian. Sehingga dari sini para pihak bebas menentukan sendiri isi perjanjian yang mereka buat. Kedua, bahwa pada umumnya seseorang menurut hukum tidak boleh dipaksa untuk memasuki suatu perjanjian. Ini berarti bahwa kebebasan bagi para pihak untuk menentukan dengan siapa dia ingin atau tidak ingin membuat suatu perjanjian. Namun perkembangan selanjutnya, perjanjian yang berdasarkan asas ini mengalami kegagalan. Hal ini terlihat adanya bukti-bukti berupa campur tangan parlemen melalui peraturan perundangundangan terhadap kebebasan berkontrak. Dari uraian di atas, menunjukkan bahwa berlakunya asas ini tidak dapat diterapkan secara mutlak. Oleh karena itu menarik untuk dikaji dasar filosofis kebebasan berjanji ini, dan batasannya.

Perkembangan kehidupan manusia demikian pesatnya, kemajuan di bidang ilmu pengetahuan dan teknologi telah merambah ke seluruh penjuru dunia, globalisasi yang melanda berbagai belahan bumi telah menembus berbagai ruang dan dimensi. Hubungan antara manusia yang satu dengan lainnya semakin komplek dan beragam. Dunia bisnis juga melaju dengan pesat, baik yang berskala nasional, bilateral, maupun internasional. Berkembangnya pasar mengakibatkan transaksi-transaksi bisnis juga semakin berkembang, transaksi tersebut umumnya dituangkan dalam suatu dokumen kontrak. Bisnis apapun hampir tidak bisa dilepaskan dari keberadaan suatu kontrak, dimana ada bisnis di situ ada kontrak ${ }^{1}$. Bahkan menurut Sir Henry Maine dalam teorinya yang terkenal perihal perkembangan hukum dari status ke kontrak sejalan dengan perkembangan masyarakat yang sederhana ke masyarakat yang modern dan kompleks, hubungan hukum yang didasarkan pada status warga-warga masyarakatyang masih sederhanaberangsurangsur akan hilang apabila masyarakat tadi berkembang menjadi masyarakat yang modern dan kompleks, hubungan-hubungan hukum didasarkan pada sistem-sistem hak dan kewajiban yang didasarkan pada kontrak yang secara sukarela dibuat dan dilakukan oleh para pihak ${ }^{2}$.

Salah satu asas yang paling menonjol dalam penyusunan kontrak adalah asas kebebasan berkontrak, yang merupakan asas universal dan dianut oleh hukum perjanjian di hampir seluruh negara di dunia pada saat ini. Dalam pustaka-pustaka yang berbahasa Inggris, asas ini dituangkan

${ }^{1}$ Munir Fuady, Hukum Bisnis Dalam Teori dan Praktek, Buku ke-empat, Citra Aditya Bakti, Bandung, 1997, hal. 3.

2 Sir Henry Maine, dalam Soerjono Soekanto, PokokPokok Sosiologi Hukum, Rajawali Pers, Jakarta, 1980, hal. 84. 
dengan berbagai istilah, antara lain Freedom of Contract, Liberty of Contract, atau Party Autonomy, di negara common law dikenal dengan istilah laissez faire yang merupakan salah satu asas yang sangat terkenal di dalam hukum kontrak. Berdasarkan asas ini suatu pihak dapat memperjanjikan dan/ atau tidak memperjanjikan apa-apa yang dikehendakinya dengan pihak lain. Namun demikian harus diakui bahwa penerapan asas berkontrak ini adalah tidak bebas sebebasbebasnya. Kebebasan berkontrak berlatar belakang pada faham individualisme yang secara embrional lahir dalam zaman Yunani, diteruskan oleh kaum Epicuristen dan berkembang pesat dalam zaman Renaisance melalui antara lain ajaran-ajaran dari Hugo de Groot, Thomas Hobbes, John Locke, dan Rosseau. Puncak perkembangannya tercapai dalam periode setelah revolusi Perancis ${ }^{3}$.

Faham individualisme melahirkan kebebasan pada setiap orang untuk memperoleh apa yang dikehendaki dan dalam perjanjian diwujudkan dalam kebebasan berkontrak. Pada tahun 1870 sebagai puncak perkembangan asas kebebasan berkontrak, setiaporang diberikan kebebasan untuk memilih siapa mitra kontraknya, bebas menentukan bentuk, isi, tujuan, dan dasar hukum dari suatu kontrak. Pemerintah maupun pengadilan sama sekali tidak dibenarkan intervensi, bahkan sampai muncul doktrin "ceveat emptor" atau "let the buyer beware" atau hukum mewajibkan pembeli untuk berhati-hati dan harus berupaya menjaga diri mereka sendiri ${ }^{4}$.

\footnotetext{
3 Mariam Darus Badrulzaman, Kompilasi Hukum Perikatan, Citra Aditya Bakti, Bandung, 2001, hal.. 84.

4 Made Rawa Aryawan, Asas Kebebasan Berkontrak
}

Amerika Serikat menjamin kebebasan berkontrak yang dituangkan dalam Konstitusi pada Article 10 ayat (1) yang terkenal dengan doktrin pelarangan pembatasan transaksi dagang (the restraint of Trade Doctrine), yang intinya adalah melarang negara-negara bagian Amerika untuk membuat undang-undang yang ikut mencampuri atau merusak kewajibankewajiban dari perjanjian-perjanjian ${ }^{5}$. Asas ini juga dikenal dalam sistem hukum Inggris, Anson berpendapat a promise more than a mere statement of intention for it imports a willingness on the part of the promiser to be bound to the person to whom it is made . Dalam sistem hukum Islam juga menjamin adanya kebebasan berkontrak sebagai salah satu syarat yang harus dipenuhi dalam membuat perjanjian, bahkan Sayid Sabiq menyatakan bahwa bukanlah perjanjian jika tanpa ada kebebasan dari kedua belah pihak $^{7}$. Dengan demikian asas kebebasan berkontrak ini tidak hanya milik Burgerlijk Wetboek (selanjutnya disebut BW), akan tetapi bersifat universal dan dianut oleh berbagai sistem hukum dan negara-negara lain.

Asas kebebasan berkontrak dalam bahasa Inggris: freedom of contract, liberty of contract, dan party autonomy. Dalam

dalam Kaitannya dengan kewenangan Hakim untuk Menilai Eksistensi Kontrak, Jurnal Ilmu Hukum Vol. 1, No. 1, 2003, hal. 1.

Hardijan Rusli, Hukum Perjanjian Indonesia dan Common Law, Pustaka Sinar Harapan, Jakarta, 1996, hal. 38.

6 Sir William ReynelAnson, Anson's: Law of Contract, edited by Anthony Gordon Guest, 25th (centenary) ed., Clarendon Press, Oxford, 1979, hal. 2.

7 Sayid Sabiq, Unsur-Unsur Dinamika dalam Islam [Anashirul Quwwah Fil Islam], diterjemahkan oleh Haryono S. Yusuf, Intermasa, Jakarta, 1981, hal. 210. 
bahasa Arab: mabda' hurriyah al-ta'aqud. Maka asas kebebasan berkontrak adalah bahwa setiap orang bebas mengadakan suatu perjanjian apa saja baik perjanjian itu sudah diatur dalam undang-undang maupun belum diatur dalam undang-undang ${ }^{8}$. Sedangkan menurut Sjahdeini asas kebebasan berkontrak adalah asas yang menekankan kebebasan para pihak yang terlibat dalam suatu perjanjian untuk dapat menyetujui klausal-klausal dari perjanjian tersebut, tanpa campur tangan pihak lain (arti dasar, yaitu tanpa batas) ${ }^{9}$. Dalam bahasa Inggris kontrak berarti: An agreement between two or more persons which creates an obligation to do or not to do a particular thing. Its essentials are completent parties, subject matter, a legal consideration, mutuallity of obligation... . The writing which contains the agreement of parties, with the terms and conditions, and which serves as a proof of the obligation. Jadi Kontrak adalah suatu persetujuan diantara dua atau lebih orang yang menciptakan kewajiban untuk melakukan atau tidak melakukan sesuatu hal khusus. Suatu kontrak dengan demikian memiliki unsur-unsur: pihak-pihak yang berkompeten, pokok yang disetujui, kewajiban timbal balik. Ciri kontrak yang utama adalah dia merupakan suatu tulisan yang memuat persetujuan dari para pihak, lengkap dengan ketentuan dan syarat, serta yang berfungsi sebagai alat bukti tentang adanya seperangkat kewajiban ${ }^{10}$.

8 A. Qirom Meliala, Pokok-Pokok Hukum Perjanjian Beserta Perkembangannya, Yogyakarta, Liberty, 1985, hal. 18.

9 Sutan Remy Sjahdeini, Kebebasan Berkontrak dan Perlindungan yang Seimbang Bagi Para Pihak Dalam Perjanjian, Jakarta, Institut Indonesia, 1993, hal. 11.

${ }^{10}$ Budiono Kusumohamidjojo, Dasar-Dasar
Berlakunya asas konsensualisme menurut hukum perjianjian Indonesia memantapkan adanya asas kebebasan berkontrak. Tanpa sepakat dari salah satu pihak yang membuat perjanjian, Tanpa sepakat maka perjanjian yang dibuat dapat dibatalkan . Orang tidak dapat dipaksa untuk memberikan sepakatnya. Sepakat yang diberikan dengan paksa adalah Contradictio interminis. Adanya paksaan menunjukkan tidak adanya sepakat yang mungkin dilakukan oleh pihak lain adalah untuk memberikan pilihan kepadanya, yaitu untuk setuju mengikatkan diri pada perjanjian yang dimaksud, atau menolak mengikatkan diri pada perjanjian dengan akibat transaksi yang diinginkan tidak terlaksana (take it or leave it).

Radbruch mengakui bahwa keadilan terhadap manusia individual merupakan batu sendi dalam perwujudan keadilan dalam hukum. Dengan demikian juga finalitas hukum kehilangan kepentingannya. Memang tetap benar, bahwa finalitas hukum dapat digabungkan dengan tiga subyek. Tetapi finalitas hukum itu menyusul kedua aspek lain. Urutan ketiga aspek ditentukan Radbruch sebagai berikut: keadilan, kepastian hukum, finalitas ${ }^{11}$. Maka bila perkembangan negara ditentukan sebagai finalitas hukum, tujuan ini tetap tunduk pada tuntutan keadilan dan kepastian hukum. Kiranya dengan ini bahaya timbulnya kesewenang-wenangan di bidang hukum dapat diatasi. Menurut $\mathrm{Hegel}^{12}$ peralihan

\footnotetext{
Merancang Kontrak, Jakarta, Grasindo, 1998, hal. 5-6. 165.

${ }^{11}$ Gustav Radbruch dalam Theo Huijbers II, hal.

${ }^{12}$ Hegel, Grundlinien, hal. 20-27.
} 
dari kebebasan pilihan yang kesewenangwenangan kea rah kebebasan rasional (eksistensial) berakar dalam keinginan akan kebahagian. Oleh sebab orang ingin menjadi bahagia mereka menentukan suatu tindakan yang sesuai dengan cita-cita pribadinya.

Para penganjur mazhab hukum alam menyatakan bahwa manusia dituntun oleh suatu asas bahwa manusia adalah bagian dari alam dan sebagai mahluk rasional dan cerdas, bertindaksesuaidengankeinginannya (desires) dan gerak hatinya (impulse). Manusia adalah agen yang merdeka (free agent), oleh karena itu merupakan hal yang wajar untuk tidak terikat yang sama wajarnya dengan terikat (that is just as natural to be unbound as it to be bound). Perilaku yang didasarkan atas pemikiran ini menciptakan aturan dan ketentuan yang diperlukan bagi suatu masyarakat yang baik. Asas moral dan asas keadilan berada di atas semua aturan hukum yang dikeluarkan oleh pemerintah, oleh karena itu perundang-undangan yang tidak sejalan dengan hukum alam adalah tidak $\operatorname{sah}^{13}$.

Salah satu penganjur terkemuka dari aliran hukum alam ini berpendapat bahwa hak untuk mengadakan perjanjian adalah salah satu dari hak asasi manusia. Hugo de Groot merupakan tokoh yang mengemukakan bahwa suatu supreme body of law yang dilandasi oleh nalar manusia (human reason) yang disebutnya sebagai hukum alam (natural law). De Groot beranggapan bahwa kontrak adalah suatu tindakan suka rela dari seseorang dimana

\footnotetext{
13 Johanes Ibrahim dan Lindawaty Sewu, Hukum Bisnis: Dalam Persepsi Manusia Modern, Refika Aditama,Bandung, 2004, hal. 104.
}

ia berjanji sesuatu kepada orang lain dengan maksud bahwa orang lain itu akan menerimanya. Kontrak tersebut adalah lebih dari sekedar suatu janji, karena suatu janji tidak memberikan hak kepada pihak yang lain atas pelaksanaan janji itu ${ }^{14}$.

Arti sentral yang ingin diberikan de Groot kepada janji-janji dapat dilihat dari kenyataan bahwa ia menyatakan bahwa kewajiban tersebut sebagai salah satu asasasas dasar hukum alam. Menurut De Groot, keseluruhan hukum positif bertumpu pada kewajiban hukum alam, Ia menghendaki agar semua institusi hukum bertumpu pada persetujuan antara manusia, baik yang dibuat secara tegas maupun secara diamdiam, dengan demikian menurut De Groot hak milik privat juga terbentuk dengan cara ini $^{15}$. Pendiskripsian selanjutnya mengenai hukum positif, oleh De Groot disebut sebagai "burgelijk wet" (undang-undang keperdataan) nampak bahwa pada dasarnya ia tidak begitu saja menerima prinsip " pacta sunt servanda". De Groot menunjukkan antara lain bahwa hukum positif telah meletakkan beberapa keterbatasan asas prinsip kebebasan untuk mengikatkan diri sedemikian rupa sehingga orang lain memperoleh sebuah hak. Hal-hal tersebut tidak saja mengakui bahwa janji-janji yang mempunyai isi tertentu dinyatakan tidak sah, misalnya bilamana bertentangan dengan ketentuan undang-undang, tetapi

${ }^{14}$ Peter Aronstam, dalam Sutan Remy Sjahdeini, Kebebasan Berkontrak dan Perlindungan yang Seimbang Bagi Para Pihak dalam Perjanjian Kredit Bank di Indonesia, Institut Bankir Indonesia, Jakarta, 1993, hal. 20.

15 Soedjono Dirdjosisworo, Kontrak Bisnis (menurut Sistem Civil Law, Common Law, dan Praktek Dagang Internasional), Mandar Maju, Bandung, 2003, hal. 88. 
juga melalui janji-janji dan kesanggupankesanggupan ${ }^{16}$.

Thomas Hobbes berpendapat bahwa alam telah membuat manusia sama, yaitu sama dalam panca indranya dan sama dalam pikirannya, sekali pun dapat dijumpai bahwa kadang-kadang ada manusia yang lebih kuat raganya dari manusia yang lain. Dari kesamaan ini timbul kesamaan harapan untuk memperoleh tujuan-tujuan akhirnya. Apabila ada dua manusia yang menginginkan hal yang sama, yang untuk hal tersebut tidak mungkin dapat dinikmati bersama oleh mereka, maka mereka akan saling bermusuhan. Untuk mencapai apa yang diinginkan oleh mereka itu, mereka akan berusaha untuk menghancurkan atau menaklukkan yang lain ${ }^{17}$. Oleh karena manusia selalu merupakan mahluk yang serakah dan akan condong untuk mengambil kembali sebagian dari hak-haknya yang telah diserahkan itu apabila dia merasa rugi karena telah melakukan hal yang demikian itu, maka sekedar mereka setuju untuk menyerahkan hak alami mereka tidaklah cukup, harus dilakukan perbuatan yang lebih daripada itu, yaitu mereka harus mengalihkan hak-hak alami mereka kepada seseorang atau suatu badan yang dapat memastikan bahwa perjanjian itu dipatuhi dengan memberikan hak kepada orang atau badan itu untuk menggunakan seluruh kekuasaan yang diperoleh dari semua pihak yang bersangkutan agar mereka mematuhi perjanjian tersebut. Dikatakan oleh Hobbes bahwa "Covenants, without the Sword, are

\footnotetext{
16 Ibid., hal. 89.

17 C.B. Macpherson, dalam Ibid., hal. 55.
}

but words, and of no strength to secure a man at all"18.

Sebagaimana telah dikemukakan di atas, maka negara yang telah dibentuk oleh rakyatnya berdasarkan perjanjian sosial (social contract) dan telah diserahi hak-hak rakyat untuk dapat bertindak dalam rangka melindungi kepentingan rakyat yang telah terlibat dalam perjanjian sosialitu, bukan saja berwenang tetapi juga berkewajiban untuk mengusahakan terjadinya keseimbangan dan keselarasan demi tercapainya keadilan bagi kepentingan dari pihak-pihak yang membuat perjanjian itu sendiri.

Mengenai hak, Immanuel Kant membedakan hak-hak alami dari hak-hak yang diperoleh, tetapi ia hanya mengakui satu hak alami, yaitu kebebasan manusia sepanjangkebebasan ini dapat berdampingan dengan kebebasan manusia menurut hukum umum. Persamaan termasuk dalam prinsip kebebasan, dari sini menyusul sejumlah hak yang bersifat individual, terutama hak untuk memiliki, yang oleh Kant (seperti halnya Locke, Hegel, dan banyak yang lain) dianggap sebagai suatu ekspresi dari suatu kepribadian $^{19}$. oleh karena itu mengenai kebebasan berkontrak ini perlu untuk dibahas prinsip-prinsipnya, karena tidak jarang suatu kontrak dapat memunculkan suatu persoalan tertentu yang terkati dengan kesalah pahaman mengenai makna dari kebebasan berkontrak itu sendiri.

\section{Pembahasan}

\footnotetext{
18 Ibid., hal. 56-57.

19 W. Friedman, Teori dan Filsafat Hukum (Legal Theory), diterjemahkan oleh Muhamad Arifin, Rajawali, Jakarta, 1990, hal. 4.
} 
Undang-Undang Dasar 1945 dan BW (Burgerlijk Wetboek) serta perundangundangan lainnya mengatur bahwa tidak ada ketentuan yang secara tegas menentukan tentang berlakunya asas kebebasan berkontrak bagi perjanjian-perjanjian yang dibuat menurut hukum Indonesia. Ada faham yang tidak setuju kebebasan berkontrak ini diletakkan sebagai asas utama Hukum Perjanjian, tetapi menurut pendapat Mariam Darus Badrulzaman: asas kebebasan berkontrak tetap perlu dipertahankan sebagai asas utama di dalam Hukum Perjanjian Nasional ${ }^{20}$. Dalam Hukum Perjanjian Nasional, asas kebebasan berkontrak yang bertanggung jawab, yang mampu memelihara keseimbangan perlu tetap dipertahankan, yaitu "pengembangan kepribadian" untuk mencapai kesejahteraan dan kebahagiaan hidup lahir dan batin yang serasi, selaras, dan seimbang dengan kepentingan masyarakat ${ }^{21}$.

Sumber dari kebebasan berkontrak adalah kebebasan individu, sehingga yang merupakan titik tolaknya adalah kepentingan individu, sehingga dapat dipahami bahwa kebebasan individu memberikan kepadanya kebebasan untuk berkontrak. Soepomo telah memberikan sumbangan yang sangat besar dalam hal peletak dasar terhadap hubungan individu dan masyarakat di Indonesia, dalam pidato inaugurasinya di Fakultas Hukum Jakarta tahun 1941 dapat disimpulkan beberapa ciri perbandingan tentang kedudukan individu dalam masyarakat di Indonesia dan Dunia

\footnotetext{
20 Badrulzaman 1, Op.Cit., hal. 85.

21 Ibid., hal. 86-87.
}

Barat, sebagai berikut: “di Indonesia, yang primair adalah masyarakat, individu terikat dalam masyarakat. Hukum bertujuan mencapai kepentingan individu yang selaras, serasi, dan seimbang dengan kepentingan masyarakat.

Di Barat, yang primair adalah individu, individu terlepas dari masyarakat, hukum bertujuan mencapai kepentingan individu"22. Menurut sejarah, Pasal 1338 BW yang dijadikan dasar berlakunya asas kebebasan berkontrak di Indonesia, berpijak pada revolusi Perancis, bahwa individu sebagai sumber kesejahteraan dan kehendak individu sebagai dasar kekuasaan melahirkan sistem individualisme dan kapitalisme ${ }^{23}$. Pada akhir abad XIX, akibat desakan faham-faham etis dan sosialis, faham individualisme mulai pudar, terlebih-lebih sejak berakhirnya perang dunia kedua, faham ini dinilai tidak mencerminkan keadilan. Masyarakat ingin pihak yang lemah lebih banyak mendapat perlindungan, oleh karena itu kehendak bebas tidak lagi diberi arti mutlak, akan tetapi diberi arti relatif, dikaitkan selalu dengan kepentingan umum. Pengaturan isi perjanjian tidak semata-mata dibiarkan kepada para pihak, akan tetapi perlu diawasi oleh pemerintah sebagai pengemban kepentingan umum, menjaga keseimbangan kepentingan individu dan kepentingan masyarakat.

Melalui penerobosan hukum perjanjian oleh pemerintah terjadi pergeseran hukum perjanjian ke bidang Hukum Publik. Melalui

\footnotetext{
${ }^{22}$ Soepomo, dalam Mariam Darus Badrulzaman 2, Aneka Hukum Bisnis, Alumni, Bandung, 1994, hal. 4445.

23 Aryawan, Loc.Cit.
} 
campur tangan pemerintah ini terjadi pemasyarakatan (vermaatschappelijking) Hukum Perjanjian ${ }^{24}$. Pasal 1338 ayat (1) BW, menyatakan bahwa semua kontrak (perjanjian) yang dibuat secara sah berlaku sebagai undang-undang bagi mereka yang membuatnya. Kata "semua" dalam Pasal tersebut mengindikasikan bahwa orang dapat membuat perjanjian apa saja, tidak terbatas pada jenis perjanjian yang diatur dalam BW, dan perjanjian tersebut akan mengikat para pihak yang membuatnya. Pasal 1338 BW itu sendiri juga menggunakan kalimat "yang dibuat secara sah", hal ini berarti bahwa apa yang disepakati antara para pihak, berlaku sebagai undang-undang selama apa yang disepakati itu adalah sah. Artinya tidak bertentangan dengan undang-undang, ketertiban umum, dan kesusilaan. Dalam hal suatu kontrak ternyata bertentangan dengan undang-undang, ketertiban umum, dan kesusilaan, kontrak tersebut batal demi hukum ${ }^{25}$ Secara historis kebebasan berkontrak mengandung makna adanya 5 (lima) macam kebebasan ${ }^{26}$, yaitu:

1. Kebebasan bagi para pihak untuk menutup atau tidak menutup kontrak;

2. Kebebasan untuk menentukan dengan siapa para pihak akan menutup kontrak;

3. Kebebasan bagi para pihak untuk

24 Badrulzaman 1, Op. cit., hal. 85.

25 Setiawan, Menurunnya Supremasi Azas Kebebasan Berkontrak, PPH Newsletter Desember, 2003. Hal.1

${ }^{26}$ Johannes Gunawan, dalam Bernadette M. Waluyo, "Hukum Perjanjian sebagai Ius Constituendum (Lege Ferenda)" dalam Aspek Hukum dari Perdagangan Bebas: Menelaah Kesiapan Hukum Indonesia dalam Melaksanakan Perdagangan Bebas, diedit oleh Ida Susanti dan Bayu Seto, Citra Aditya Bakti, 2003, Bandung, hal. 60-61. menentukan bentuk kontrak;

4. Kebebasan bagi para pihak untuk menentukan isi kontrak;

5. Kebebasan bagi para pihak untuk menentukan cara pembuatan kontrak.

Adapun menurut Az-Zarqa, kebebasan berkontrak meliputi :

1. Kebebasan untuk mengadakan atau tidak mengadakan perjanjian.

2. Tidak terikat kepada formalitasformalitas, tetapi cukup semata-mata berdasarkan kata sepakat.

3. Point kedua ini sebenarnya tidak termasuk kebebasan berkontrak, tetapi merupakan asas konsensualisme (persesuaian kehendak).

4. Tidak terikat kepada perjanjianperjanjian bernama.

5. Artinya bahwa tidak terikat pada perikatan bernama yang sudah ada. Boleh membuat perikatan/perjanjian baru.

6. Kebebasan untuk menentukan akibat perjanjian.

Berlakunya asas konsensualisme menurut hukum perjianjian Indonesia memantapkan adanya asas kebebasan berkontrak. Tanpa sepakat dari salah satu pihak yang membuat perjanjian, maka perjanjian yang dibuat dapat dibatalkan. Orang tidak dapat dipaksa untuk memberikan sepakatnya, sepakat yang diberikan dengan paksa adalah Contradictio interminis. Adanya paksaan menunjukkan tidak adanya sepakat yang mungkin dilakukan oleh pihak 
lain adalah untuk memberikan pilihan kepadanya, yaitu untuk setuju mengikatkan diri pada perjanjian yang dimaksud, atau menolak mengikatkan diri pada perjanjian dengan akibat transaksi yang diinginkan tidak terlaksana (take it or leave it). Menurut hukum perjanjian Indonesia, seseorang bebas untuk membuat perjanjian dengan pihak manapun yang dikehendakinya.

Undang-undang hanya mengatur orang-orang tertentu yang tidak cakap untuk membuat perjanjian, pengaturan mengenai hal ini dapat dilihat dalam Pasal 1330 BW. Dari ketentuan ini dapat disimpulkan bahwa setiap orang bebas untuk memilih pihak yang ia inginkan untuk membuat perjanjian, asalkan pihak tersebut bukan pihak yang tidak cakap. Bahkan lebih lanjut dalam Pasal 1331 BW ditentukan bahwa apabila seseorang membuat perjanjian dengan pihak yang dianggap tidak cakap menurut pasal 1330 BW tersebut, maka perjanjian itu tetap sah selama tidak dituntut pembatalannya oleh pihak yang tidak cakap (voidable). Larangan kepada seseorang untuk membuat perjanjian dalam bentuk tertentu yang dikehendakinya juga tidak diatur dalam BW Indonesia maupun ketentuan perundangundangan lainnya.

Ketentuan yang ada adalah bahwa untuk perjanjian tertentu harus dibuat dalam bentuk tertentu misalnya perjanjian kuasa memasang hipotik harus dibuat dengan akta notaris atau perjanjian jual beli tanah harus dibuat dengan Pejabat Pembuat Akta Tanah (PPAT). Dengan demikian dapat disimpulkan bahwa sepanjang ketentuan perundang-undangan tidak menentukan bahwa suatu perjanjian harus dibuat dalam bentuk tertentu, maka para pihak bebas untuk memilih bentuk perjanjian yang dikehendaki, yaitu apakah perjanjian akan dibuat secara lisan atau tertulis atau perjanjian dibuat dengan akta di bawah tangan atau akta otentik. Pasal 1320 ayat (1) BW menentukan bahwa perjanjian atau kontrak tidak sah apabila dibuat tanpa adanya konsensus atau sepakat dari para pihak yang membuatnya. Ketentuan tersebut mengandung pengertian bahwa kebebasan suatu pihak untuk menentukan isi perjanjian dibatasi oleh sepakat pihak lainnya. Dalam Pasal 1320 ayat (2) BW dapat pula disimpulkan bahwa kebebasan orang untuk membuat perjanjian dibatasi oleh kecakapannya untuk membuat perjanjian. Bagi seseorang yang menurut ketentuan undang-undang tidak cakap untuk membuat perjanjian sama sekali tidak mempunyai kebebasan untuk membuat perjanjian.

Pasal 1320 ayat (3) BW menentukan bahwa obyek perjanjian haruslah dapat ditentukan. Prestasi itu harus tertentu atau sekurang-kurangnya dapat ditentukan, apa yang diperjanjikan harus cukup jelas ditentukan jenisnya, jumlahnya boleh tidak disebutkan asal dapat dihitung atau ditetapkan. Lebih lanjut dalam Pasal 1332 BW menyebutkan bahwa hanya barangbarang yang dapat diperdagangkan saja yang dapat menjadi pokok suatu perjanjian. Syarat bahwa prestasi harus tertentu atau dapat ditentukan gunanya adalah untuk menetapkan hak dan kewajiban kedua belah pihak jika timbul perselisihan dalam pelaksanaan perjanjian. Apabila prestasi 
samar (kabur) atau dirasakan kurang jelas yang menyebabkan perjanjian itu tidak dapat dilaksanakan, maka obyek perjanjian dianggap tidak ada (null) dan akibat hukumnya perjanjian tersebut batal demi hukum. Pasal 1320 ayat (4) jo. Pasal 1337 BW menentukan bahwa para pihak tidak bebas untuk membuat perjanjian yang menyangkut kausa yang dilarang oleh undang-undang. Kausa atau sebab yang diperbolehkan itu apabila tidak dilarang oleh undang-undang dan tidak bertentangan dengan ketertiban umum dan kesusilaan. Akibat hukum atas perjanjian yang berisi sebab yang tidak diperbolehkan adalah bahwa perjanjian tersebut batal demi hukum.

Pembatasan terhadap asas kebebasan berkontrak juga dapat disimpulkan melalui Pasal 1338 ayat (3) BW yang menyatakan bahwa suatu perjanjian hanya dilaksanakan dengan itikad baik. Oleh karena itu para pihak tidak dapat menentukan sekehendak hatinya klausul-klausul yang terdapat dalam perjanjiian tetapi harus didasarkan dan dilaksanakan dengan itikad baik, perjanjian yang didasarkan pada itikad buruk misalnya penipuan. Akibat hukum atas perjanjian tersebut adalah dapat dibatalkan. Sehubungan dengan pembatasan terhadap asas kebebasan berkontrak, Asikin Kusuma Atmadja menyatakan bahwa Hakim berwenang untuk memasuki/meneliti isi suatu kontrak apabila diperlukan, karena isi dan pelaksanaan suatu kontrak bertentangan dengan nilai-nilai dalam masyarakat ${ }^{27}$.

\footnotetext{
27 Asikin Kesuma Atmadja, "Pembatasan Rentenir sebagai Perwujudan Pemerataan Keadilan," Varia Peradilan (Februari 1987), hal. 17.
}

Berarti dalam keadaan tertentu hakim berwenang melalui tafsiran hukum untuk meneliti dan menilai serta menyatakan bahwa kedudukan para pihak dalam suatu perjanjian berada dalam keadaan yang tidak seimbang sedemikian rupa, sehingga salah satu pihak dianggap tidak bebas untuk menyatakan kehendaknya. Asikin Kusuma Atmadja lebih lanjut mengatakan bahwa kebebasan berkontrak yang murni/mutlak karena para pihak kedudukannya seimbang sepenuhnya praktis tidak ada, selalu ada pihak yang lebih lemah dari pihak yang lain. Penyalahgunaan kesempatan atau penyalahgunaan keadaan (misbruik van omstandigheden) dapat digunakan dalam kategori cacat dalam menentukan kehendak untuk memberikan persetujuan, hal ini dapat dijadikan alasan oleh hakim untuk menyatakan batal atau membatalkan suatu perjanjian yang tidak diatur dalam undangundang yang merupakan suatu konstruksi yang dapat dikembangkan melalui yurisprudensi.

Senada dengan batasan-batasan kebebasan berkontrak di atas, menurut Subekti, bahwa hukum perjanjian menganut sistem terbuka dalam arti hukum perjanjian memberikan kebebasan yang seluas-luasnya kepada masyarakat untuk mengadakan perjanjian yang berisi apa saja, asalkan tidak melanggar ketertiban umum dan kesusilaan $^{28}$. Salah satu penerapan asas kebebasan berkontrak misalnya dapat kita lihat dalam perbankan. Pada dasarnya, kebebasan berkontrak hanya bisa mencapai

${ }^{28}$ Subekti, Hukum Perjanjian, Intermasa, Jakarta, 1992, hal. 13 . 
tujuannya bila para pihak mempunyai bergaining position yang seimbang. Namun dalam perkembangan selanjutnya, operasional perjanjian khususnya dunia perbankan nasional misalnya, dimana salah satu pihak memiliki bergaining position yang lebih kuat dari pihak yang lain sehingga dapat memaksakan kehendaknya untuk menekan pihak lain tanpa adanya negosiasi/ kompromi ${ }^{29}$. Inilah kemudian salah satu yang dikenal dengan perjanjian baku yang dalam perjanjian perbankan. Maka dalam kaitannya dengan asas kebebasan berkontrak ini, terdapat kekurangan-kekurangan. Karena syarat-syarat ditentukan secara sepihak, sedangkan pihak lainnya terpaksa menerima apa adanya.

Salah satu keadaan yang dapat disalahgunakan ialah adanya kekuasaan ekonomi (economish overwicht) pada salah satu pihak yang menggangu keseimbangan antara kedua belah pihak, sehingga adanya kehendak yang bebas untuk memberikan persetujuan yang merupakan salah satu syarat bagi sahnya suatu persetujuan tidak ada (kehendak yang cacat). Di sini terletak wewenang hakim untuk menggunakan interpretasi sebagai sarana hukum untuk melumpuhkan perjanjian yang tidak seimbang. Banyak faktor yang dapat memberikan indikasi tentang adanya penyalahgunaan kekuasaan ekonomi untuk dipertimbangkan, umpamanya terdapat syarat-syarat yang diperjanjikan yang sebenarnya tidak masuk akal atau yang

${ }^{29}$ Ronny Sautma Hotma Bako, Hubungan Bank dan Nasabah Terhadap Produk Tabungan dan Deposito: Suatu Tinjauan Hukum Terhadap Perlindungan Deposan di Indonesia Dewasa Ini, Citra Aditya Bakti, Bandung, 1995, hal. 25-26. tidak patut atau bertentangan dengan perikemanusiaan. Demikian halnya apabila ternyata pihak debitur berada dalam keadaan tertekan (dwang positie), juga apabila terdapat keadaan dimana bagi debitur tidak ada pilihan lain kecuali mengadakan perjanjian dengan syarat-syarat yang memberatkan.

Dari telaah tersebut di atas, tampak jelas bahwa hubungan antara asas kebebasan berkontrak yang berlaku di Indonesia dengan segala pembatasannya adalah sesuai dan sejalan dengan kebebasan berkontrak yang dikemukakan oleh beberapa tokoh mazhab hukum alam (Hugo de Groot, Thomas Hobbes, maupun Immanuel Kant) yang sangat menjunjung tinggi moralitas dan keadilan, hal ini tercermin dari adanya keharusan kepada para pihak untuk tidak menentukan sekehendak hatinya klausulklausulyangterdapat dalam perjanjiian tetapi harus didasarkan dan dilaksanakan dengan itikad baik. Selain itu juga adalah tetap diperlukannya peran serta pemerintah untuk mengusahakan terjadinya keseimbangan dan keselarasan demi tercapainya keadilan bagi kepentingan pihak-pihak yang membuat perjanjian itu sendiri.

\section{Penutup}

Kontrak mengasumsikan adanya individu yang bebas dan setara dengan cara masing-masing. Dalam masyarakat sipil kontrak merupakan sarana mendasar untuk menentukan kepemilikan, dalam masyarakat tersebut kontrak hanya disaingi oleh pemberian dan pewarisan sebagai sarana mentransfer barang dan kekayaan dari suatu 
individu ke individu lain. Sebagaimana jual beli barang di pasar didasarkan pada kontrak, kontrak tidak sekedar mencirikan transaksi yang sifatnya kadang-kadang atau tidak sering, ini merupakan hubungan materi yang khas dalam masyarakat kapitalis modern. Kontrak merupakan sarana yang lazim dimana pemilik kekayaan disatukan bersama secara sosial. Dengan demikian, cara individu dalam berhubungan satu sama lain diharapkan dapat memebentuk sifat bagi masyarakat secara keseluruhan. Apa yang sebenarnya didapatkan dalam sebuah kontrak adalah kendali terhadap kehendak orang lain berkenaan dengan tindakan yang dijanjikan. Kegagalan melaksanakan tindakan yang dijanjikan, karenanya tidak berarti bahwa pihak lain dalam kontrak itu secara otomatis memiliki hak atas obyek atau layanan yang dibeli. Kegagalan mematuhi ketentuan di sini adalah bahwa individu yang melanggar dapat dihukum, bukan obyeknya yang harus dipindahtangankannya.

Perjanjian melambangkan ketidakpastian dan kekurangpercayaan dalam hubungan empiris antar manusia dalam masyarakat sipil. Dari sudut pandang empiris, tidak ada alasan pendorong untuk menghormati perjanjian jika kita tidak berkepentinganuntukmenghormatinya.Oleh karena itu kontrak membutuhkan dukungan positif dari hukum agar bisa berlangsung dalam masyarakat sipil. Individu bolehjadi terdorong oleh sisi paling mendasarnya untuk melakukan tindakan yang tidak terpuji yang pada tingkatan fenomenal hanya bisa dicegah dengan menggunakan pemaksaan. Bila semuanya gagal, pemaksaan harus menjadi jalan terakhir untuk memastikan bahwa kontrak itu terealisasi.

\section{Daftar Bacaan}

Munir Fuady, Hukum Bisnis Dalam Teori dan Praktek, Buku ke-empat, Citra Aditya Bakti, Bandung, 1997.

Sir Henry Maine, dalam Soerjono Soekanto, Pokok-Pokok Sosiologi Hukum, Rajawali Pers, Jakarta, 1980.

Mariam Darus Badrulzaman, Kompilasi Hukum Perikatan, Citra Aditya Bakti, Bandung, 2001.

Made Rawa Aryawan, Asas Kebebasan Berkontrak dalam Kaitannya dengan kewenangan Hakim untuk Menilai Eksistensi Kontrak, Jurnal Ilmu Hukum Vol. 1, No. 1, 2003.

Hardijan Rusli, Hukum Perjanjian Indonesia dan Common Law, Pustaka Sinar Harapan, Jakarta, 1996.

Sir William Reynel Anson, Anson's: Law of Contract, edited by Anthony Gordon Guest, 25th (centenary) ed., Clarendon Press, Oxford, 1979.

Sayid Sabiq, Unsur-Unsur Dinamika dalam Islam [Anashirul Quwwah Fil Islam], diterjemahkan oleh Haryono S. Yusuf, Intermasa, Jakarta, 1981.

A. Qirom Meliala, Pokok-Pokok Hukum PerjanjianBesertaPerkembangannya, Yogyakarta, Liberty, 1985.

Sutan Remy Sjahdeini, Kebebasan Berkontrak dan Perlindungan yang Seimbang Bagi Para Pihak Dalam Perjanjian, Jakarta, Institut Indonesia, 1993.

Budiono Kusumohamidjojo, DasarDasar Merancang Kontrak, Jakarta, Grasindo, 1998. 
Johanes Ibrahim dan Lindawaty Sewu, Hukum Bisnis: Dalam Persepsi Manusia Modern, Refika Aditama,Bandung, 2004.

Peter Aronstam, dalam Sutan Remy Sjahdeini, Kebebasan Berkontrak dan Perlindungan yang Seimbang Bagi Para Pihak dalam Perjanjian Kredit Bank di Indonesia, Institut Bankir Indonesia, Jakarta, 1993.

Soedjono Dirdjosisworo, Kontrak Bisnis (menurut Sistem Civil Law, Common Law, dan Praktek Dagang Internasional), Mandar Maju, Bandung, 2003,

W. Friedman, Teori dan Filsafat Hukum (Legal Theory), diterjemahkan oleh Muhamad Arifin, Rajawali, Jakarta, 1990.

Soepomo, dalam Mariam Darus Badrulzaman 2, Aneka Hukum Bisnis, Alumni, Bandung, 1994.

Setiawan, Menurunnya Supremasi Azas Kebebasan Berkontrak, PPH Newsletter Desember, 2003.
Johannes Gunawan, dalam Bernadette M. Waluyo, "Hukum Perjanjian sebagai Ius Constituendum (Lege Ferenda)" dalam Aspek Hukum dari Perdagangan Bebas: Menelaah Kesiapan Hukum Indonesia dalam Melaksanakan Perdagangan Bebas, diedit oleh Ida Susanti dan Bayu Seto, Citra Aditya Bakti, 2003, Bandung.

Asikin Kesuma Atmadja, "Pembatasan Rentenir sebagai Perwujudan Pemerataan Keadilan," Varia Peradilan (Februari 1987).

Subekti, Hukum Perjanjian, Intermasa, Jakarta, 1992.

Ronny Sautma Hotma Bako, Hubungan Bank dan Nasabah Terhadap Produk Tabungan dan Deposito: Suatu Tinjauan Hukum Terhadap Perlindungan Deposan di Indonesia Dewasa Ini, Citra Aditya Bakti, Bandung, 1995. 